\title{
Democratic People's Republic of Korea Initiative
}

\section{Export Control Issues for the Proposed PNNL Energy Efficiency Center in North Korea}
A. C. Rither
D. A. Varley

January 2001

Prepared for

the U.S. Department of Energy

under Contract DE-AC06-76RL01830

Pacific Northwest National Laboratory

Richland, Washington 99352 


\title{
DISCLAIMER
}

This report was prepared as an account of work sponsored by an agency of the United States Government. Neither the United States Government nor any agency thereof, nor Battelle Memorial Institute, nor any of their employees, makes any warranty, express or implied, or assumes any legal liability or responsibility for the accuracy, completeness, or usefulness of any information, apparatus, product, or process disclosed, or represents that its use would not infringe privately owned rights. Reference herein to any specific commercial product, process, or service by trade name, trademark, manufacturer, or otherwise does not necessarily constitute or imply its endorsement, recommendation, or favoring by the United States Government or any agency thereof, or Battelle Memorial Institute. The views and opinions of authors expressed herein do not necessarily state or reflect those of the United States Government or any agency thereof.

\author{
PACIFIC NORTHWEST NATIONAL LABORATORY \\ operated by \\ BATTELLE \\ for the \\ UNITED STATES DEPARTMENT OF ENERGY \\ under Contract DE-AC06-76RL01830
}

Printed in the United States of America

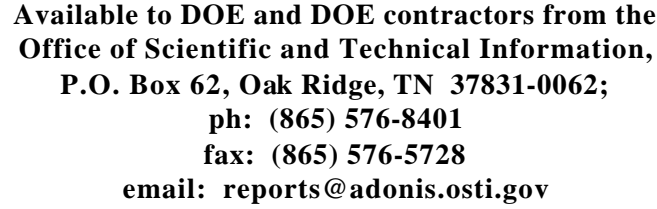

Available to the public from the National Technical Information Service, U.S. Department of Commerce, 5285 Port Royal Rd., Springfield, VA 22161 ph: (800) 553-6847 fax: $(703) 605-6900$

email: orders@ntis.fedworld.gov online ordering: http://www.ntis.gov/ordering.htm 
PNNL-13425

\section{Democratic People's Republic of Korea Initiative}
A. C. Rither
D. A. Varley

January 2001

Pacific Northwest National Laboratory

Richland, Washington 99352 


\begin{abstract}
The Democratic People's Republic of Korea (DPRK, also called North Korea) has expressed an interest in establishing an Energy Efficiency Center to improve the energy efficiency of North Korea's economy and living conditions. This Center would concentrate on evaluating how these conditions affect the North Korean people. Currently their system(s) seems quite antiquated. Establishing a center that could advise and monitor activity would be a humanitarian effort by the U.S. government and the scientific community working on the program. This Center could impact energy policy for the government of DPRK and private industry within its borders. U.S. government export control regulations and any licensing application will need to be determined before initial startup can begin.
\end{abstract}




\section{Contents}

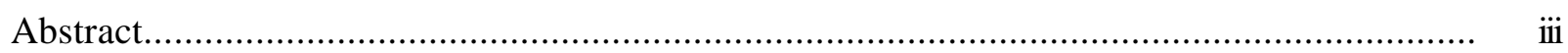

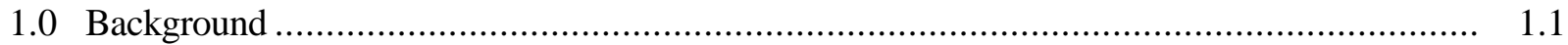

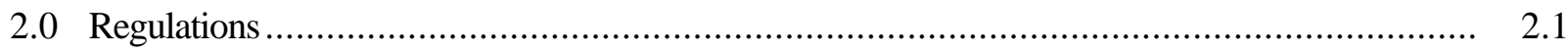

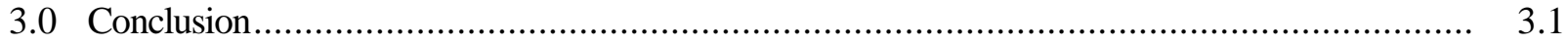

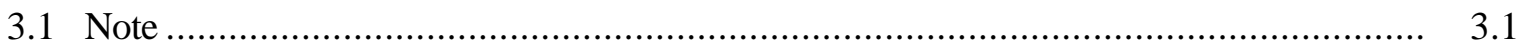

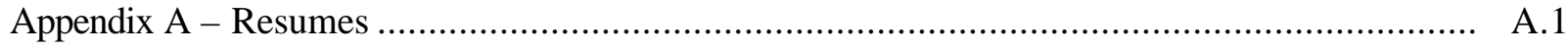

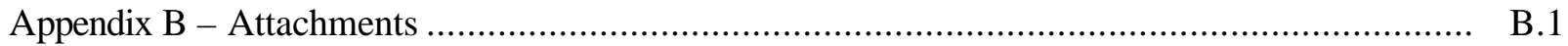




\subsection{Background}

Pacific Northwest National Laboratory (PNNL) has established similar centers in the following countries, thereby establishing a precedent: Poland, Czech Republic, Russia, China, Bulgaria and Ukraine. The current centers, in the beginning were established and funded by private and public entities. They currently are financially independent. To date they continue to impact the energy policies for their respective countries and improvements to energy efficiency have been viewed as highly successful.

North Korea's Energy Center will be patterned similarly to the Beijing Energy Efficiency Center (BECon), China. The reason for the similarity is that the two countries have similar cultural and political relationships. Hopefully, BECon and the DPRK Center will interact well with each other because of their cultural and political similarities.

A request has been made to determine the possible Export Control restrictions that may be incurred by the Department of Energy/PNNL and other relevant government agencies when establishing this Center in the DPRK. This letter report was developed to assist the project as they move forward establishing this Center. Information has been gathered and determinations made concerning Export Control regulations that are applicable when dealing with the DPRK. 


\subsection{Regulations}

Government regulations pertaining to Export Controlled information and technology can be secured from several agencies: Department of Commerce, Bureau of Export Administration (BXA) Export Regulations 15 CFR Parts 730-774, Department of Energy Assistance to Foreign Atomic Energy Activities 10 CFR Part 810, Department of State International Traffic in Arms Regulations 22 CFR Parts 120-130 and the Department of Treasury, Foreign Assets Control Regulations, 31 CFR Part 500.

Revisions to the BXA regulations were issued pursuant to direction from President Clinton on November 30, 2000.

The Applicable government regulations for the DPRK project (see Appendix B - Attachments) are:

- Attachment 1 - Department of Commerce, Press release for June 22, 2000, Easing of Sanctions for North Korea

- Attachment 2 - Press release for June 19, 2000, BXA Fact sheet Easing of Sanctions for North Korea

- Attachment 3 - Department of Treasury, An overview (fact sheet) of the Foreign Assets Control Regulations as they relate to North Korea, Title 31 Part 500

- Attachment 4 - Code of Federal Regulations, Title 31, Money and Finance: Treasury Section 500.586, Korea, new actions relating to Korea, June 19, 2000 (BXA Regs.)

The Department of Energy and the Department of State regulations do not apply because the DPRK project as it is currently envisioned involves neither nuclear technology nor military equipment and technology. 


\subsection{Conclusion}

During our review we determined that export of energy-efficiency technology and/or equipment as proposed does not require a license, but may be carried out under various license exceptions that are available. This determination is based on the information provided to PNNL Export Control Coordinator that identified the kinds of information and equipment that would be provided to the Center.

In the future, as changes to the program develop, the program may have to re-evaluate the issue of any required license(s).

\subsection{Note}

The DPRK government may consider certain information about its energy usage to be a state secret. Care should be taken to obtain a clear and authoritative statement that all energy efficiency information developed by the Center may be publicly disclosed. 


\title{
Appendix A
}

\author{
Resumes
}




\section{Alan C. Rither \\ Senior Attorney}

\section{Organization: Legal Department}

\section{Past Experience:}

Alan Rither joined Battelle Memorial Institute at the Pacific Northwest National Laboratory in 1973, shortly after graduating from the University of Washington School of Law. He began work in the Contracts Department, serving as Manager, Contract Services, where he was responsible for about 20 staff involved in negotiating and administering research contracts for Battelle. In 1982 he became Manager, Subcontracts, where he was responsible for about 30 staff involved in placing nearly $\$ 100$ million per year in subcontracts for research and other services to support the mission of the Laboratory. He became a Certified Professional Contracts Manager by the National Contract Management Association (NCMA) in 1976, and was elected a Fellow of the NCMA in 1997.

In 1985, he transferred to the Legal Department of Battelle as Senior Attorney, and has been involved primarily with providing legal advice concerning contractual matters, serving as the laboratory Export Control Coordinator, and providing legal advice on Security matters.

He is co-founder and past national Chair of the Department of Energy's Export Control Coordinators Organization, and is Vice-Chair of Battelle's Institutional Review Board for Human Subjects Research, and a member of its Institutional Animal Care and Use Committee. He is the past Chair (1995-1996) of the International Practice Section of the Washington State Bar Association. He taught an accredited course on Government Contract Law for Columbia Basin College as an adjunct faculty member during the 1995 school year and is doing so again in fall 2000.

In addition to his professional activities, he is active and holds positions in the following organizations:

- Member of the Christian Legal Society

- Fellow and Certified Professional Contracts Manager of the National Contract Management Association Trustee of the Kadlec Medical Center Foundation

- Member of the Board of Directors of Kadlec Medical Center

- Life member of the Reserve Officers Association

- Vice president of the Board of Radiant Light Broadcasting

- Member of the Board of the Alliance for the Advancement of Science Through Astronomy (AASTA)

- Member of the Board of the Herbert M. Parker Foundation

- Chairman of the Board of Richland Assembly of God

Alan and his wife, Kathy, have lived in Richland since 1973. They have two children: David, age 17, and Sara, age 14. 
Darlene A. Varley

Senior Information Release/

Export Control Specialist

Organization:

Quality Directorate, Records and Information Management (RIM Section)

\section{Current Activities and Projects:}

Ms. Varley has been with the Pacific Northwest National Laboratory for 20 years. She is the Senior Information Release/Export Control Specialist in the Quality Directorate. She is responsible for ensuring that legal and programmatic reviews are completed on Scientific and Technical Information (STI) products for the Laboratory. She is the official Releasing Officer overseeing the release of laboratorygenerated STI products to the public through the Office of Scientific and Technical Information (OSTI) and the Hanford Technical Library. She represents Information Release on PNNL's Web Review team by reviewing and approving web sites. She is certified to review and determine Export Control on PNNL and Hanford Site documents and assists with the Export Control function on Hanford Site documents for PNNL. Darlene is the System Manager for the Sensitive Country Information Logging System and assists the legal office as Deputy Export Control Coordinator in matters relating to export licensing. She currently processes all license applications to the Department of Commerce for the Laboratory. She is a key member of the Electronic Records and Information Capture Architecture (ERICA) team as they develop the electronic capture process for STI and Laboratory Records.

\section{Past Experience:}

Ms. Varley has worked for Battelle since 1981. Her early years at the Lab related to clearance and release of STI. She is considered a resource for the Lab in all aspects of the publishing process. In the mid1990's Darlene was offered the opportunity to expand her area of expertise into Export Control. This included becoming the Deputy Export Control Coordinator for the Legal Office, a certified ECI reviewer and trainer for the administrative aspects for the ECI Training offered to Lab and Hanford Site staff. Prior work history included Azurdata, Inc.

\section{Awards and Honors:}

\section{National Awards:}

1999 HAMMER Award for the Scientific and Technical Information Program Community Team.

1997 U.S. Department of Energy Certification of Appreciation for Vigilance in Operations Security (OPSEC)

\section{Laboratory Awards:}

Outstanding Team Performance Award for Recognition of National HAMMER Award (2000) 
Outstanding Team Performance Award in Recognition of the 1998 National Operations Security (OPSEC) Award Nominee - Organizational Achievement (1998)

Outstanding Team Performance Award for Participation in Train-the-Trainer on Export Control and Technology Transfer (1997)

Communication Directorate Award of Distinction for her year-long voluntary commitment to the Hanford 50 $^{\text {th }}$ Anniversary Celebration

\section{Honors:}

Ms. Varley was Vice Chairman of the Export Control Coordinators Organization for 1998-1999 and Chairman for 1999-2000. This honor included co-chairing the annual ECCO Training Seminar with another ECCO member.

Ms. Varley served as Chair of the Battelle Women's Forum from 1998-1999 and was a member of the Lab's Supportive Work Environment Advisory Board 1997-2000. She also has been chairman for several American Cancer Society activities at the Lab. In addition, she has served as Chairman of the Annual Take Our Daughters to Work Day for three years. 
Appendix B

Attachments 

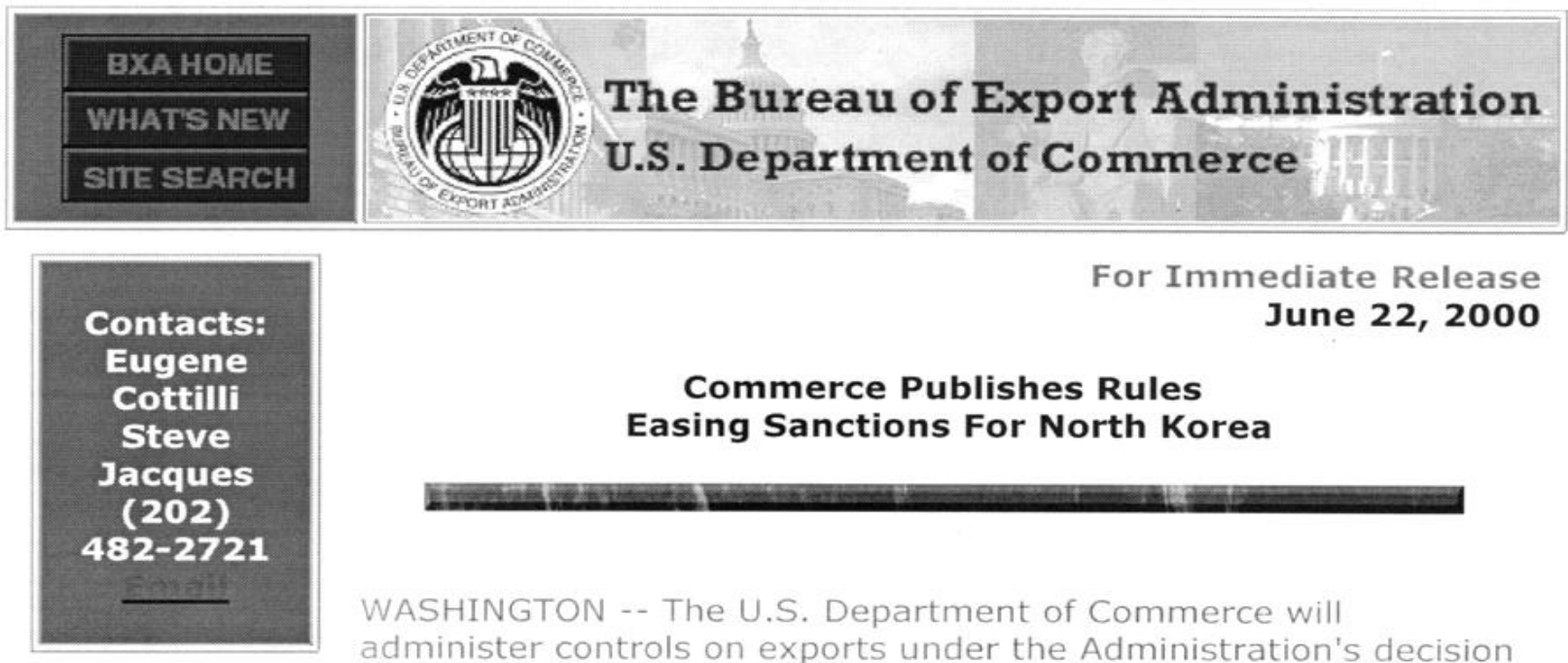

For Immediate Release

June 22, 2000

\author{
Commerce Publishes Rules \\ Easing Sanctions For North Korea
}

WASHINGTON -- The U.S. Department of Commerce will

administer controls on exports under the Administration's decision to ease trade sanctions on North Korea. Regulations detailing the conditions, which allow North Korea to receive most U.S. consumer products without a license, were published today and include agricultural, medical, and low-level industrial goods and services. The new rules are effective immediately.

The Administration's sanctions easing program continues to require a license for items on the Commerce Control List (CCL), including items added specifically for continued control to North Korea. This includes items controlled multilaterally for nuclear, missile and chemical-biological weapons reasons, as well as a range of lower-level products and technologies controlled for antiterrorism and nonproliferation reasons.

Items controlled for antiterrorism reasons to North Korea include: aircraft and aircraft parts; encryption products; most telecommunications equipment; and computers at or above six MTOPS. License applications for computers up to 2,000 MTOPS to nonmilitary or non-nuclear end-users will be reviewed on a case-by-case basis. BXA also created several new entries on the $\mathrm{CCL}$ to control specific production equipment and software for North Korea.

To view the Federal Register publication implementing the sanctions easing program for North Korea, refer to www.gpo.gov/bxa. Also, refer to BXA's Web site at www.bxa.doc.gov. for specific questions and answers on exporting to North Korea. 
BXA HOME

WHATS NEV

SITE SEARCH

June 19,2000

\title{
BXA facts
}

\author{
Sanctions Easing for North Korea
}

In response to improved U.S.- North Korean relations, the Bureau of Export Administration (BXA) today published regulations easing sanctions on North Korea. This implements the Administration's September 1999 decision to ease sanctions provided North Korea maintains its moratorium on testing long-range ballistic missiles. North Korea may now receive the vast majority of U.S. consumer products without a license, including agricultural, medical, and low-level industrial goods and services.

The Administration's sanctions easing program continues to require a license for items on the Commerce Control List (CCL), including additional items added to the CCL by today's regulation. Items on the $\mathrm{CCL}$ include multilaterally controlled items, as well as a range of lower-level products and technologies controlled for anti-terrorism and non-proliferation reasons. Items controlled for anti-terrorism reasons to North Korea include: aircraft and aircraft parts; encryption products; most telecommunications equipment; and computers at or above 6 MTOPS. License applications for computers up to 2,000 MTOPS to non-military or non-nuclear end-users will be reviewed on a case-by-case basis. BXA also created several new entries on the CCL to control specific production equipment and software for North Korea.

Other agencies have taken related measures. The Transportation Department, in conjunction with the Commerce Department, published a rule to lift the ban on U.S. ships and aircraft transporting goods or traveling to North Korea. Previously, U.S. registered ships and aircraft were prohibited from engaging in such activities. The

Treasury Department amended its regulations to allow new financial, trade and other transactions with North Korea and its nationals. Treasury will require a notification and approval process for all imports from North Korea.

Federal Register text of new rule.

\section{Questions and Answers: Exports to North Korea}

\section{Did BXA add any new Export Commodity Control Numbers (ECCNs) to the CCL for North Korea?}

Yes. BXA added several new ECCNs to control certain processing equipment, materials and software for North Korea. The new ECCNs include: 0A999, 0B999, 0D999, 1A999, 1B999, 1C999, 1D999,

$2 A 999,2 B 999,3 A 999$, and 6A999. Note that these new ECCNs do not refer to any column on the Country Chart and, therefore, exporters are not required to consult the Country Chart to determine licensing requirements. 


\section{Do EAR99 items require a license for export or reexport to North Korea?}

No. Items classified as EAR99 may generally be exported and reexported to North Korea without a license. Exporters should indicate NLR (No License Required) in the appropriate entry on the Shipper's Export Declaration. However, exporters should always consult the "know your customer" and "red flags" guidance in Supplement No. 3 to Part 732 of the EAR when exporting to North Korea. In addition, the General Prohibitions continue to apply, including end-use and end-user restrictions maintained under BXA's Enhanced Proliferation Control provisions in Part 744 of the EAR. Exporters should also note that some items previously considered EAR99 are now controlled for North Korea in several new ECCNs; see the discussion in the response to Question\#1.

\section{Are my products included in the new ECCNs?}

The new ECCNs include certain production equipment and software; refer to the technical specifications of the new ECCNs to determine if your product falls within the scope of items controlled. BXA, as always, will classify your product for you if necessary (see Section 748.3 of the EAR for information on submitting a classification request).

\section{May I export EAR99 items to government end-users in North Korea without a license?}

Yes. EAR99 items may generally be exported to government end-users in North Korea without a license. However, a license is required to export EAR99 items to North Korean end-users involved in missile, nuclear, or chemical/biological weapons proliferation (refer to Part 744 of the EAR for licensing requirements and policy).

\section{North Korea is a closed society, how do I know if my end-user is a government entity or involved in proliferation activities?}

Exporters should always refer to the "know your customer" and "red flags" guidance in Supplement No. 3 to Part 732 of the EAR. In addition, BXA may inform exporters, either individually or through Federal Register publication, that a license is required for exports to specific North Korean end-users due to proliferation concerns. Exporters are encouraged to request a BXA advisory opinion when unsure of the status or activities of a North Korean end-user (refer to Section 748.3 of the EAR for guidance on submitting such a request).

\section{What is BXA's policy for items on the CCL requiring a license for North Korea?}

License applications for exports to North Korean military, nuclear, missile, and chemical/biological end-use and end-users are generally subject to denial. License applications for exports to other North Korean end-users will be considered on a case-by-case basis (see Section 742.19 and Supplement No. 2 to Part 742 of the EAR for further information). 
7. Do imports from North Korea require a U.S. government license?

Yes. Refer to the Department of Treasury, Office of Foreign Assets Control (OFAC), for guidance. This guidance is available at their Web site in PDF format. Click on the N. Korea Button when you get to the site.

B.4 


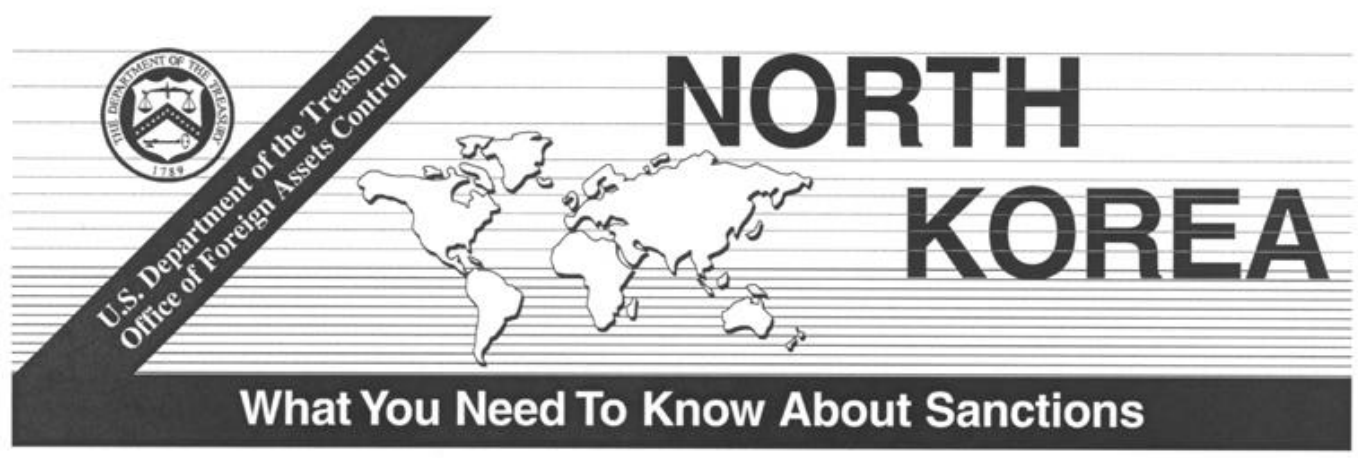

\section{An overview of the Foreign Assets Control Regulations as they relate to North Korea Title 31 Part 500 of the U.S. Code of Federal Regulations}

- INTRODUCTION - The Foreign Assets Control Regulations, authorized under the Trading with the Enemy Act, established economic sanctions against the Democratic People's Republic of Korea ("North Korea") in 1950. They have been modified on several occasions, most recently on June 19,2000, as a result of President Clinton's September 17, 1999 decision to ease economic sanctions against North Korea in order to improve relations, to support the Agreed Frame. work, and to encourage North Korea to continue to refrain from testing long-range missles. The Regulations affect all U.S. citizens and permanent residents wherever they are located, all people and organizations physically in the United States. and all branches, subsidiaries and controlled affliates of U.S. Organizations throughout the world. They are administered by the U.S. Treasury Department's Office of Foreign Assets Control. Penalties for violating the sanctions range up to 10 years in prison, $\$ 1,000,000$ in corporate fines, and $\$ 250,000$ in individual fines. Civil penalties of up to $\$ 55,000$ per count may also be imposed.

This fact sheet is a broad summary of the Regulations.

a SELLING TO NORTH KOREA - The June 19, 2000 amendments to the Foreign Assets Control Regulations ended the ban on exports to North Korea, provided that any exports or reexports to North Korea are licensed or otherwise authorized by the Department of Commerce or other appropriate agencies.

- BUYING FROM NORTH KOREA - Pursuant to Sections 73 and 74 of the Arms Export Control Act (22 U.S.C. \$\$2 $2797 \mathrm{~b}-2797 \mathrm{c}$ ), goods of North Korean origin may without prior notification to and approvat of the Office of Foreign Assets Control.

Importers must provide OFAC with written information as to whether the products to be imported were produced by (a) a foreign person designated by the Secretary
of State as having engaged in missle technology proliferation activities; (b) an activity of the North Korean Government relating to the development or production of any missile equipment or technology; or (c) an activity of the North Korean Government affecting the development or production of electronics, space systerns or equipment, and military aircraft.
In addition to the information just described, importers seeking an approval letter from OFAC must provide their name, address, telephone, fax, and e-mail ad dresses; a description of the product to be imported, including quantity and cost: the name and address of the producer of the product: the name of the location where the product was produced; and the name and address of the North Korean exporter. Requests for import review must be submitted by mail to North Korea Unit, Office of Foreign Assets Control, U.S. NW, Annex. Washington, DC 20220. After reviewing the information. OFAC will issue a letter indicating the results of the review to the person seeking to impont the product.

U.S. depository institutions handling letters of credit or documentary collections involving imports from North Korea must obtain a copy of OFAC's approval letter involving imports from North Korea must obtain a copy of OFAC's approval letter provided to the U. Customs Sevice before imports trom North Kort also be allowed into the United States.

- TRAVELING TO NORTH KOREA - U.S. passports are valid for travel to North Korea and individuals do not need U.S. Government permission to travel there. All Korea and individuals donoineed U.S. Government permissionto travel there. A maintenance within North Korea are authorized. U.S. travel service providers to maintone within North Korea are authorized. U.S. travel somice providers are Korean carriers.

- ACCOUNTS, ASSETS, AND FINANCIAL TRANSACTIONS - Property blocked as of June 16,2000 remains blocked. All other transactions are authorized, provided Asseat the crileria oullined in the June 19, 2000 amendments to the Foreign Assots Control Regulations described elsewhere in this summary. Remitters and cociplonts need to know that translers from the North Korean Government that constiule donations toU.S. persons or with respect to which a U.S. person knows, terrorist acts in the United States are still prohibited.

This document is explanatory only and does not have the force of law. The Executive Orders and implementing regulations relating to North Korea contain the legally binding provisions governing the sanctions and this document does not supplement or modify those Executive Orders or regulations.

The Treasury Department's Office of Foreign Assets Control also administers sanctions programs involving Iraq, Libya, the Federal Republic of Yugoslavia, the Republic of Serbia, Cuba, the National Union for the Total Independence of Angola (UNITA), Iran, Syria, Sudan, Burma (Myanmar), designated international terrorists and narcotics traffickers, Foreign Terrorist Organizations, and designated foreign persons who have engaged in activities related to the proliferation of weapons of mass destruction. For additional information about these programs or about the North Korean sanctions program, please contact the:

OFFICE OF FOREIGN ASSETS CONTROL

U.S. Department of the Treasury
Washington, D.C. 20220

$2021622 \cdot 2490$ 
Sec. 500.586 Authorization of new transactions concerning certain North Korean property.

(a) Subject to the limitations in paragraph (b) of this section, transactions in which North Korea or a national thereof has an interest are authorized where:

(1) The property comes within the jurisdiction of the United states or into the control or possession of a person subject to the jurisdiction of the United States on or after June 19, 2000; or

(2) The interest in the property of North Korea or a North Korean national arises on or after June 19, 2000.

(b) (1) Unless otherwise authorized by the office of Foreign Assets Control, all property and interests in property of North Korea or its nationals that were blocked pursuant to subpart $B$ of this part as of June 16, 2000, remain blocked and subject to the prohibitions and requirements of this part;

(2) (i) The importation of products into the United States from North Korea requires approval from the office of Foreign Assets Control. The person seeking to import products into the United States must provide information relevant to the determination whether the product was produced by

(A) A foreign person whose actions triggered import sanctions under sections 73 and 74 of the Arms Export Control Act;

(B) An activity of the government of North Korea relating to the development or production of any missile equipment or technology; or

(C) An activity of the government of North Korea affecting the development or production of electronics, space systems or equipment, and military aircraft.

(ii) Those seeking to import products from North Korea into the United states must submit all available information satisfying the requirements of paragraph (b) (2) (i) of this section; the name, address, telephone number, facsimile number, and e-mail address of the importer; a description of the product to be imported, including quantity and cost; the name and address of the producer of the product; the name of the location where the product was produced; and the name and address of the North Korean exporter. Requests for import review should be submitted by mail to North Korea Unit, office of Foreign Assets Control, U.S. Department of the Treasury, 1500 Pennsylvania Avenue, NW, Annex, Washington, DC 20220. Upon review of the submitted information, the Office of Foreign Assets Control will issue a letter indicating the results of the review to the person seeking to import the product.

(3) Except as authorized by Sec. 500.580 or unless otherwise authorized by the office of Foreign Assets Control, persons subject to the jurisdiction of the United states are prohibited from engaging in any transfer from the government of North Korea:

(i) Constituting a donation to a person subject to the jurisdiction of the United States; or

(ii) With respect to which a person subject to the jurisdiction of the United States knows (including knowledge based on advice from an agent of the United States Government), or has reasonable cause to 
believe, that the transfer poses a risk of furthering terrorist acts in the United States.

(4) This section does not affect any open enforcement action initiated by the U.S. government prior to June 19, 2000 or any seizure, forfeiture, penalty, or liquidated damages case that is considered closed in accordance with U.S. Customs or other agency regulations. This section also does not authorize the importation into the United States

\section{[ [Page 515]]}

of goods that are under seizure or detention by U.S. Customs officials pursuant to Customs laws or other applicable provision of law, until any applicable penalties, charges, duties or other conditions are satisfied. This section does not authorize importation into the United States of goods for which forfeiture proceedings have been commenced or of goods that have been forfeited to the U.S. Government, other than though U.S. Customs disposition by selling at auction.

Note to Sec. $500.586(\mathrm{~b})$ : The exportation and reexportation of items may be subject to license application requirements under regulations administered by other federal agencies (see e.g., the Export Administration Regulations administered by the Department of Commerce). Section 500.533 of this part continues to provide authority for transactions incident to the exportation and reexportation of items authorized by the Department of Commerce. It should also be noted that the shipment of strategic goods from a foreign country to North Korea by persons subject to the jurisdiction of the United States remains prohibited by 31 CFR part 505. The application requirements for a specific license relating to such goods are found in 31 CFR 501.801.

[65 FR 38165, June 19, 2000] 